Journal of African History, 29 (1988), 3, i-ii

Printed in Great Britain

\title{
MICHAEL CROWDER
}

WiTh GREAT REGRET, the Fournal of African History records the death of Michael Crowder, at the age of 54, on 14 August 1988, in London. He had been an editor of the fournal since 1985 .

Michael Crowder's career as a historian of Africa was unconventional, highly productive and remarkably influential. His interest in Africa was aroused during National Service in the Nigeria Regiment, in 1953-4. On graduating from Oxford in 1957, he travelled extensively in West Africa; he described these journeys in his first book, Pagans and Politicians (1959), which is illustrated with many of his own excellent photographs. From 1959 to 1962 he was back in Lagos, editing Nigeria Magazine and writing The Story of Nigeria ( 1962 and later editions); this was followed by a study for the Institute of Race Relations, Senegal: a study in French assimilation (1962). From 1962 to 1964 Michael was secretary of the Institute of African Studies at the University of Ibadan; in 1964-5 he taught at the University of California, Berkeley; and in 1965-7 was director of the Institute of African Studies, Fourah Bay College. During these years he wrote West Africa under Colonial Rule (1968), a largescale survey based in part on research in national archives when those in Britain were still subject to a fifty-year rule. In 1968-71 Michael was director of the Institute of African Studies at the University of Ife; from 197I to 1975 he was professor of history at Ahmadu Bello University, Zaria. This period bore fruit in several collaborative ventures for which Michael recruited numerous African contributors: West African Chiefs (edited with Obaro Ikime) (1970); West African Resistance (1971); and the two volumes of the History of West Africa (edited with J. F. Ade Ajayi) (197I, 1974; later editions). Michael also produced his own first research monograph, Revolt in Bussa (1973), a local study of early colonial administration in Northern Nigeria. From 1975 to 1978 he was professor at the newly formed Centre of Cultural Studies at the University of Lagos. He published West Africa : an introduction to its history (1977) and brought together essays of his own in Colonial West Africa (1978). He also put in hand two further large-scale collaborations: the Historical Atlas of Africa with J. F. Ade Ajayi (1985) and volume 8 (c. 1940-c. 1975) of the Cambridge History of Africa (1984).

In 1979, after almost twenty years in West Africa, mostly in Nigeria, Michael returned to London to become editor of the monthly History Today, in the first change of editorship since its foundation in 1951 . From 1982 to 1985 he was professor of history at the University of Botswana. This appointment characteristically stimulated him to develop an entirely new direction for his own research: with access to materials unavailable to earlier writers, he embarked on a new biography of Tshekedi Khama. ${ }^{1}$ This project (which was close to completion when Michael died) had various offshoots, including two books published in 1988: an edition (with Neil Parsons) of the diaries of Tshekedi's antagonist C. F. Rey, and a micro-study of one notorious incident

1 See Michael Crowder, 'Tshekedi Khama and opposition to the British Administration of the Bechuanaland Protectorate, 1926-1936', $\mathcal{F}$. Afr. Hist., xxvi (1985), ii-iii, 193-2 I 4. 
in Tshekedi's career, The Flogging of Phinehas McIntosh. In I986 Michael became general editor of the British Documents on the End of Empire Project, with a base at the Institute of Commonwealth Studies, London (whose first director, Sir Keith Hancock, died the day before Michael, aged 90). Meanwhile, in 1986, Michael taught for one term at Deakin University, Victoria, Australia, and in 1987-8 two semesters at Amherst College, Massachusetts. He was about to take up a fellowship at the Woodrow Wilson Center in the Smithsonian Institution, Washington, D.C., when he was struck down by illness.

Michael Crowder's career spanned the growth to academic maturity of African history, and African studies in general. He and his books supplied an invaluable counterpoint to the progress of contemporaries working their way up the conventional academic ladder. From the first, Michael sought to engage the interest of intelligent readers at large, rather than a narrow group of specialists. His non-academic path into the study of African history accustomed him to write in order to give pleasure as well as instruction - an aim that has become sadly rare both within and beyond Africanist circles. As he moved into the thick of university life in West Africa, Michael developed a remarkable talent for enabling academics to communicate with one another, while proving himself to be a conscientious and creative scholar. He joined the editorial team of the Fournal of African History at a critical moment in the fortunes of the fournal, and despite spells abroad and many other pressing duties he gave promptly and unstintingly of his time and energy. For the stimulus of his company, his critical acumen, his concern for clarity and his broad vision of the possibilities of African history, he is sorely missed. 